\title{
Cysteine cathepsin S processes leptin, inactivating its biological activity
}

\author{
Marcela Oliveira ${ }^{1}$, Diego M Assis ${ }^{1}$, Thaysa Paschoalin ${ }^{2}$, Antonio Miranda ${ }^{1}$, Eliane B Ribeiro ${ }^{3}$, \\ Maria A Juliano ${ }^{1}$, Dieter Brömme ${ }^{4}$, Marcelo Augusto Christoffolete ${ }^{5}$, Nilana M T Barros ${ }^{1,6}$ \\ and Adriana K Carmona ${ }^{1}$ \\ ${ }^{1}$ Departamento de Biofísica, Universidade Federal de São Paulo, Rua Pedro de Toledo 669, São Paulo, São Paulo 04039-032, Brazil \\ ${ }^{2}$ Departmento de Microbiologia, Imunologia e Parasitologia and ${ }^{3}$ Departamento de Fisiologia, Universidade Federal de São Paulo, São Paulo, \\ São Paulo 04023-062, Brazil \\ ${ }^{4}$ Department of Oral Biological and Medical Sciences, University of British Columbia, Vancouver, BC, Canada V6T 1Z3 \\ ${ }^{5}$ Centro de Ciências Naturais e Humanas, Universidade Federal do ABC, Santo André, São Paulo 09210-170, Brazil \\ ${ }^{6}$ Departamento de Ciências Exatas e da Terra, Universidade Federal de São Paulo, Diadema, São Paulo 09972-270, Brazil \\ (Correspondence should be addressed to A K Carmona; Email: ak.carmona@unifesp.br; N M T Barros at Departamento de Biofísica, Universidade Federal \\ de São Paulo; Email: nilana.barros@unifesp.br)
}

\begin{abstract}
Leptin is a $16 \mathrm{kDa}$ hormone mainly produced by adipocytes that plays an important role in many biological events including the regulation of appetite and energy balance, atherosclerosis, osteogenesis, angiogenesis, the immune response, and inflammation. The search for proteolytic enzymes capable of processing leptin prompted us to investigate the action of cysteine cathepsins on human leptin degradation. In this study, we observed high cysteine peptidase expression and hydrolytic activity in white adipose tissue (WAT), which was capable of degrading leptin. Considering these results, we investigated whether
\end{abstract}

recombinant human cysteine cathepsins B, K, L, and S were able to degrade human leptin. Mass spectrometry analysis revealed that among the tested enzymes, cathepsin $\mathrm{S}$ exhibited the highest catalytic activity on leptin. Furthermore, using a Matrigel assay, we observed that the leptin fragments generated by cathepsin S digestion did not exhibit angiogenic action on endothelial cells and were unable to inhibit food intake in Wistar rats after intracerebroventricular administration. Taken together, these results suggest that cysteine cathepsins may be putative leptin activity regulators in WAT. Journal of Endocrinology (2012) 214, 217-224

\section{Introduction}

Leptin is a small protein primarily produced by adipocytes, consists of 167 amino acid residues, and is encoded by the $o b$ gene on chromosome 6 , the murine homolog of the human leptin gene LEP. The role of leptin in energy homeostasis is demonstrated in the genetic obese mouse $(\mathrm{Ob} / \mathrm{Ob})$, which exhibits profound obesity, type II diabetes, and hyperphagia (Zhang et al. 1994, Tartaglia 1997, Lago et al. 2007). In addition to its important function in regulating food intake (Zhang et al. 1994, Attele et al. 2002, Sahu 2004), leptin is involved in several processes such as angiogenesis (Anagnostoulis et al. 2008), blood pressure control (Haynes 2005), osteogenesis (Bertoni et al. 2009), fertility (Thomas et al. 2004), immune response, inflammation (Lago et al. 2007), and atherosclerosis (Taleb et al. 2007).

The activities of leptin are mediated through its receptor (OB-R), which is encoded by the diabetes $(d b($ Lepr $)$ ) gene on chromosome 4 . Leptin receptor null mice $(d b / d b)$ exhibit a phenotype similar to that of $o b / o b$ mice, which is used as a model for obesity (Tartaglia 1997). The clearance of leptin by the kidneys is believed to be the end point of leptin action, and the bioavailability of leptin is defined by the ratio of free/bound leptin (Huang et al. 2001, Lammert et al. 2001).

Recent studies have shown that the cysteine peptidases cathepsins L, S, and $\mathrm{K}$ are present in the adipose tissue (Naour et al. 2010), and these cathepsins are thought to be important molecules in adipogenesis and atherosclerosis (Lafarge et al. 2010, Naour et al. 2010). Although human cathepsins were initially associated with the protein recycling machinery, they are also implicated in a variety of events outside the lysosomes or present on cell membranes where they participate in selective and controlled processes (Turk et al. 2000, 2012, Vasiljeva et al. 2007). This feature is specifically supported by cathepsin S, which is involved in many pathophysiological processes (reviewed in Arnlow (2012)), such as atherosclerosis (Sukhova et al. 2003) and adipogenesis (Taleb et al. 2005, $2006 a, b)$. Cathepsin S has been reported to be a marker of obesity and is highly correlated with body mass index (Taleb et al. 2005), overexpressed in obese human subjects, and shows decreased expression after induced weight loss (Taleb et al. 2005). Furthermore, the cathepsin S gene is one of the most deregulated genes in the adipose tissue of obese subjects (Naour et al. 2010). 
Despite the description that both lysosomal and proteasomal pathways contribute to the degradation of leptin (Rau et al. 1999, Uotani et al. 1999, Lee \& Fried 2006), the enzymes involved in the processing of this adipokine have not been described yet. In the present work, we demonstrated that leptin is processed by cysteine cathepsins and that cathepsin S renders leptin inactive, suggesting that cysteine cathepsins are key elements in leptin physiology.

\section{Materials and Methods}

\section{Animals and experimental surgery}

Fifteen male Wistar rats at 12-14 weeks of age weighing 240-260 g were submitted to i.c.v. cannula implantation as described previously (Telles et al. 2003). Two days later, the correct placement of the cannulae was assessed by a rapid dipsogenic response to angiotensin II $(20 \mathrm{ng} / \mathrm{l})$, and the animals that presented a positive response were selected, allowed to recover from surgery for at least 5 days, and separated into three animal groups containing five rats each. Then, the animals were submitted to i.c.v. injections of $10 \mu \mathrm{g}$ leptin (group 1), $10 \mu \mathrm{g}$ leptin incubated with $0.24 \mu \mathrm{M}$ cathepsin S (group 2), and $10 \mu \mathrm{g}$ leptin incubated with $0.24 \mu \mathrm{M}$ heatinactivated cathepsin S (group 3). The incubations were performed in $50 \mathrm{mM}$ sodium phosphate buffer, $\mathrm{pH}$ 6.0, for $1 \mathrm{~h}$ at $37^{\circ} \mathrm{C}$. The injections were repeated for 3 days in $24 \mathrm{~h}$ intervals, and the weights of the animals and food intake were measured daily. Statistical analysis of food intake data was performed using two-way ANOVA followed by Bonferroni's posttests. $P<0.05$ was considered statistically significant. All procedures were conducted in accordance with the Ethics Committee of Federal University of São Paulo (Brazil) and by the Animal Care Committee from the Institute of Biomedical Sciences, University of São Paulo (Brazil). Epididymal white adipose tissue (WAT) was obtained from C57B16/J mice that had free access to food and water in a $12 \mathrm{~h}$ light: $12 \mathrm{~h}$ darkness cycle in a ventilated cabinet (Alesco Ind. \& Com. Ltd., Monte Mor, SP, Brazil). The animals were killed by cardiac exsanguination under anesthesia. WAT samples were sonicated in buffer containing $50 \mathrm{mM}$ sodium phosphate, $\mathrm{pH} 6.0$, and quantified using a BCA protein assay (Pierce Biotechnology, Inc., Rockford, IL, USA) with BSA as a standard.

\section{Proteins}

Recombinant human leptin was purchased from $\mathrm{R} \& \mathrm{D}$ (Minneapolis, MN, USA). The recombinant human cathepsins S and K were expressed in Pichia pastoris, as described previously (Linnevers et al. 1997). Cathepsins L and B were purchased from Sigma Chemical Co. The molar concentrations of the studied cathepsins were determined by active site titration with E-64 according to the method previously described (Barrett et al. 1982).

\section{RNA extraction and RT-quantitative PCR}

Total RNA from epididymal WAT was extracted using TRIzol reagent (Invitrogen Inc.). Total RNA $(2.5 \mathrm{mg})$ was reverse transcribed using the first-strand cDNA synthesis (Invitrogen) and submitted to PCR using the Quantitect Sybr green master mix (Qiagen) on a MX3005P thermocycler (Agilent Technologies, Santa Clara, CA, USA). Cycling conditions were $50^{\circ} \mathrm{C}$ for 2 min followed by $95^{\circ} \mathrm{C}$ for $10 \mathrm{~min}$ (Hot start), 50 cycles at $95^{\circ} \mathrm{C}$ for $15 \mathrm{~s} ; 60^{\circ} \mathrm{C}$ for $25 \mathrm{~s}$, and $72{ }^{\circ} \mathrm{C}$ for $30 \mathrm{~s}$. Acquisition was done at the $72{ }^{\circ} \mathrm{C}$ step. Primers used were sense $5^{\prime}$-tccccagaatcttgtggact- $3^{\prime}$ and antisense $5^{\prime}$-tcttcagggctttctcgttc- $3^{\prime}$ for cathepsin $\mathrm{K}$, sense $5^{\prime}$-gcctcaggtgtttgaaccat- $3^{\prime}$ and antisense $5^{\prime}$-gttgctgtattccccgttgt- $3^{\prime}$ for cathepsin L, and sense $5^{\prime}$-ccattgggatctctggaaga- $3^{\prime}$ and antisense $5^{\prime}$-ttcatgcccacttggtaggt- $3^{\prime}$ for cathepsin S. Cyclophilin A was used as internal control (Christoffolete et al. 2006).

\section{WAT cysteine peptidase catalytic activity}

The cysteine peptidase activity in WAT lysates $(10 \mu \mathrm{g})$ was determined using $10 \mu \mathrm{M}$ fluorogenic peptide benzyloxycarbonyl-L-phenylalanyl-L-arginine-4-methylcoumaryl-7amide (Z-FR-MCA; Sigma Chemical Co.) as a substrate. The assays were performed in $50 \mathrm{mM}$ sodium phosphate, $\mathrm{pH}$ 6.0, at $37^{\circ} \mathrm{C}$. The cysteine proteases present in the extract were preactivated with $1.0 \mathrm{mM}$ dithiothreitol (DTT) for $5 \mathrm{~min}$ before the addition of the substrate. The hydrolysis was continuously monitored using a Hitachi F-2000 fluorimeter and the increase in fluorescence was measured at $\lambda_{\mathrm{em}}=380$ and $\lambda_{\mathrm{ex}}=460 \mathrm{~nm}$. To define the specificity for cysteine peptidases, the assays were also performed in the presence of specific cysteine inhibitor E-64 $(5 \mu \mathrm{M})$. The measurements were performed in triplicate, and the results are expressed as mean \pm s.D.

\section{Leptin cleavage assay by cysteine proteases}

Human recombinant leptin $(24 \mu \mathrm{M})$ was incubated with WAT lysates $(10 \mu \mathrm{g})$ in $50 \mathrm{mM}$ sodium phosphate, $\mathrm{pH}$ 6.0 , at $37^{\circ} \mathrm{C}$ for $60 \mathrm{~min}$ in the presence or absence of E-64 $(5 \mu \mathrm{M})$. After incubation, the samples were separated on a $12.5 \%$ SDS-PAGE gel and electroblotted onto a nitrocellulose membrane. Subsequently, the membrane was washed with PBS solution and incubated with antihuman leptin monoclonal antibody (primary antibody 1:1500; Sigma Chemical Co.). The membrane was then washed again with PBS and incubated with IgG-rabbit conjugated with peroxidase (secondary antibody 1:2500; Sigma Chemical Co.). TMB (3,3', 5, $5^{\prime}$ - tetramethyl benzidine) membrane peroxidase substrate was used as a substrate.

The recombinant human cathepsins were preactivated with $1.0 \mathrm{mM}$ DTT in $50 \mathrm{mM}$ sodium phosphate, $\mathrm{pH}$ 6.0, at $37^{\circ} \mathrm{C}$ for $5 \mathrm{~min}$, and the catalytic activities of the enzymes were analyzed in the same buffer at $37^{\circ} \mathrm{C}$ using 
$10 \mu \mathrm{M}$ Z-FR-MCA as a substrate. The hydrolysis was monitored for $10 \mathrm{~min}$ in a Hitachi fluorimeter F-2000 at $\lambda_{\text {ex }}=380$ and $\lambda_{\text {em }}=460 \mathrm{~nm}$. Subsequently, the active cathepsins $(0.24 \mu \mathrm{M})$ were incubated with recombinant human leptin $(24 \mu \mathrm{M})$ for $15 \mathrm{~min}$ in $50 \mathrm{mM}$ sodium phosphate, $\mathrm{pH} 6.0$ or $\mathrm{pH} 7.0$, at $37^{\circ} \mathrm{C}$. In another set of experiments, $24 \mu \mathrm{M}$ leptin was incubated with $0.24 \mu \mathrm{M}, 0.4 \mu \mathrm{M}$, or $2.4 \mu \mathrm{M}$ of recombinant human cathepsin $\mathrm{S}$ in $50 \mathrm{mM}$ sodium phosphate, $\mathrm{pH} 6.0$, for $15 \mathrm{~min}$ at $37^{\circ} \mathrm{C}$. To confirm the specificity of the assay, $5 \mu \mathrm{M}$ inhibitor E-64 was preincubated for $5 \mathrm{~min}$ with $2.4 \mu \mathrm{M}$ of cathepsin $\mathrm{S}$ before the addition of leptin. Subsequently, the samples were subjected to mass spectrometric analyses or were separated on $12.5 \%$ SDS-polyacrylamide gels. An unstained protein molecular weight marker (Fermentas, Hanover, MD, USA) was used as a molecular mass standard.

Mass spectrometry analysis of leptin processing by cysteine cathepsins

The cleavage of leptin $(24 \mu \mathrm{M})$ by cathepsins B, K, L, and S $(0.24 \mu \mathrm{M}$ of each) was analyzed using a Matrix-assisted laser desorption/ionisation-time of flight mass spectrometry (MALDI-TOF/MS) mass spectrometer (Bruker Daltonics, Bremen, Germany). The samples were incubated in $50 \mathrm{mM}$ sodium phosphate buffer, $\mathrm{pH} 6.0$ or $\mathrm{pH} 7.4$, for $1 \mathrm{~h}$ at $37^{\circ} \mathrm{C}$. The assay with cathepsin S $(0.24 \mu \mathrm{M})$ was also performed in the presence of $5 \mu \mathrm{l} \mathrm{E-64}$. Subsequently, the samples were mixed $(1: 1)$ in sinapinic acid $(10 \mathrm{mg} / \mathrm{ml})$ matrix solution and $2 \mu \mathrm{l}$ sample was spotted onto the MALDI target plate and dried at room temperature. The mass spectra were obtained operating in linear, positive ion mode previously calibrated with serum melittin and horse heart cytochrome $c$. For the analysis of leptin control, a pulsed ion extraction delay of $250 \mathrm{~ns}$, ion source voltages of 20 and $18.25 \mathrm{kV}$, and an ion source lens voltage of $7.00 \mathrm{kV}$ were used. The spectra were acquired by accumulating 50 laser shots at $90 \%$ laser power in the $m / z$ range of $18-75 \mathrm{kDa}$. The analysis of leptin fragments formed by cathepsin $\mathrm{S}$ hydrolysis was performed using a pulsed ion extraction delay of $260 \mathrm{~ns}$, ion source voltages of 20 and $18.50 \mathrm{kV}$, and an ion source lens voltage of $8.50 \mathrm{kV}$. The spectra were acquired by accumulating 50 laser shots at $32 \%$ laser power in the $\mathrm{m} / \mathrm{z}$ range of 2-20 kDa.

\section{In vitro angiogenesis assay on Matrigel}

BD Matrigel Matrix (B and D Biosciences, Bedford, MA, USA) was thawed on ice and then $15 \mu \mathrm{l} /$ well were distributed into 96-well plates and allowed to polymerize for $1 \mathrm{~h}$ at $37^{\circ} \mathrm{C}$. Then, leptin $(1 \mu \mathrm{M})$, cathepsin $\mathrm{S}(15 \mathrm{nM})$, and leptin in the presence of cathepsin S were incubated for $1 \mathrm{~h}$ at $37^{\circ} \mathrm{C}$ and submitted to heating inactivation. The samples were added to $100 \mu \mathrm{l}$ RPMI medium supplemented with $0.2 \%$ FCS containing the $5 \times 10^{3}$ cells/well human umbilical vein endothelial cells (HUVECs). The plates were incubated at $37^{\circ} \mathrm{C}$ for $18 \mathrm{~h}$, and the number of pro-angiogenic structures (closed rings) per well was counted as described previously (Paschoalin et al. 2007). The assays were carried out in triplicate, and the average value was determined for each sample. As a control, HUVECs were plated on Matrigel without any addition. Statistical analysis was performed using one-way ANOVA followed by Newman-Keuls posttest. Significance was set as $P<0.05$.
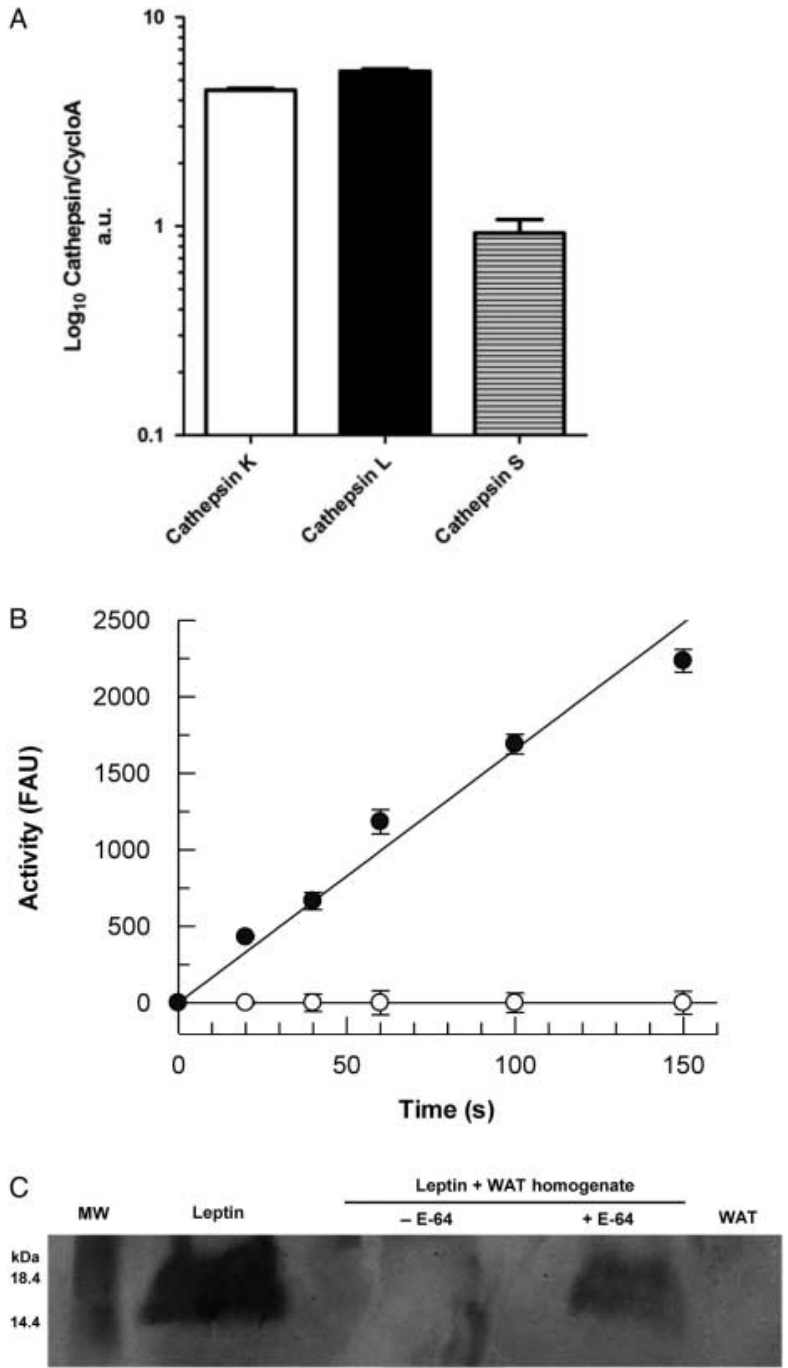

Figure 1 Cysteine peptidase in epididymal WAT. (A) Real-time analyses of cathepsins in WAT. (B) Measurements of WAT $(10 \mu \mathrm{g})$ proteolytic activity in $50 \mathrm{mM}$ sodium phosphate buffer, $\mathrm{pH}$ 6.0, using Z-FR-MCA $(10 \mu \mathrm{M})$ as a substrate in the absence (filled circle) or presence (open circle) of E-64 $(5 \mu \mathrm{M})$. (C) Activity of WAT $(10 \mu \mathrm{g})$ on exogenous recombinant human leptin $(10 \mu \mathrm{g})$ followed by immunoblotting analysis using leptin monoclonal antibody. 


\section{Results}

\section{Cathepsins in WAT are able to degrade leptin}

The WAT RT-qPCR analyses indicated that there are high levels of cathepsins $\mathrm{L}$ and $\mathrm{K}$ expression and a moderate expression of cathepsin S in epididymal WAT (Fig. 1A). The catalytic activity of cysteine peptidase in mouse WAT extract $(10 \mu \mathrm{g})$ was monitored using Z-FR-MCA as a substrate $(10 \mu \mathrm{M})$ in the presence or absence of E-64 $(5 \mu \mathrm{M})$.
The results revealed a high hydrolytic activity completely abolished in the presence of specific cysteine protease inhibitor E-64 (Fig. 1B). To investigate this endogenous WAT activity on leptin, mouse WATs $(20 \mu \mathrm{g})$ were incubated with human recombinant leptin (exogenous) with or without E-64 $(5 \mu \mathrm{M})$. The proteolytic activity after $2 \mathrm{~h}$ of incubation at $\mathrm{pH} 6.0$ was analyzed on a SDS gel electrophoresis followed by immunoblotting using human leptin monoclonal antibody. The results demonstrated that the endogenous WAT cysteine enzymes are able to degrade leptin (Fig. 1C).
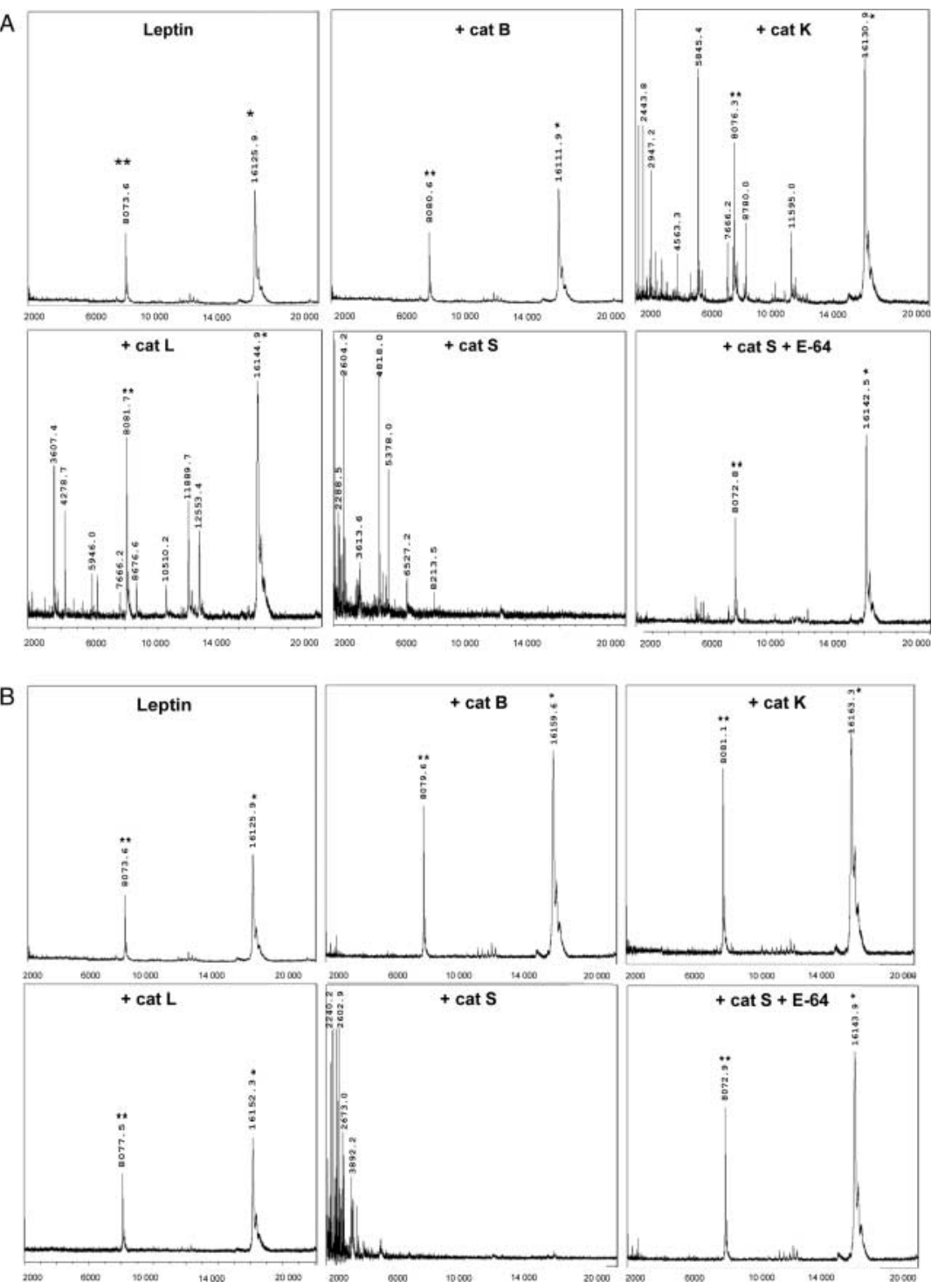

Figure 2 Mass spectral analysis of leptin hydrolysis by cathepsins at $\mathrm{pH} 6.0$ and 7.4. Human recombinant leptin was incubated at $\mathrm{pH} 6.0$ (A) and $\mathrm{pH} 7.4$ (B) with cathepsin $\mathrm{B}$ (cat $\mathrm{B})$, cathepsin K (cat K), cathepsin L (cat L), and cathepsin S (cat S) in the absence or presence of $5 \mu \mathrm{M}$ E-64. The fragments resulting from hydrolysis were detected by MALDI-TOF/MS. The experimental procedure details are presented in Materials and Methods section.

$*(\text { Leptin mass }+\mathrm{H})^{+}$and $* *(\text { Leptin mass }+2 \mathrm{H})^{2+} / 2$. 


\section{Leptin is efficiently degraded by cathepsin $S$}

Initially, to verify the involvement of cysteine cathepsins in leptin degradation, human recombinant cathepsins B, L, K, and $\mathrm{S}(0.24 \mu \mathrm{M})$ were incubated with human recombinant leptin $(24 \mu \mathrm{M})$ at $\mathrm{pH}$ 6.0. The proteolytic activity after 15 min of incubation was analyzed by mass spectrometry. Our results showed that at $\mathrm{pH}$ 6.0, leptin was slightly hydrolyzed by cathepsins B, L, and $\mathrm{K}$, whereas cathepsin S was the most efficient, generating small fragments (Fig. 2A). In addition, considering the broad $\mathrm{pH}$ profile presented by cathepsin $\mathrm{S}$ (Kirschke et al. 1989), we extended our investigation at $\mathrm{pH}$ 7.4. A mass spectrometric analysis demonstrated that at neutral $\mathrm{pH}$, cathepsin $\mathrm{S}$ was still able to degrade leptin into small peptides, whereas no hydrolysis was observed with cathepsins B, L, and K (Fig. 2B). Furthermore, analyses using different concentrations of cathepsin $\mathrm{S}$ confirmed this high efficiency of leptin hydrolysis (Fig. 3A). Considering the already well-described cathepsin $\mathrm{S}$ substrate specificity (Choe et al. 2006, Lutzner \& Kalbacher 2008, Oliveira et al. 2010), we have suggested potential cleavage sites for cathepsin $\mathrm{S}$ in the leptin sequence (Fig. 3B).

\section{Cathepsin S inactivates leptin biological activity}

The biological activity of leptin after cathepsin S cleavage was evaluated in vitro and in vivo. We first explored the well-known leptin effect on angiogenesis stimulation (Anagnostoulis et al. 2008) and examined whether the leptin fragments generated by cathepsin $\mathrm{S}$ hydrolysis were still able to evoke a biological response. As expected, leptin presents a pro-angiogenic effect by generating closed intercellular compartments arising from endothelial cell sprouting (pro-angiogenic structures; Fig. 4). This response was completely abolished in cells treated with the products of leptin incubation with cathepsin S, whereas cathepsin $\mathrm{S}$ alone had no effect on angiogenesis when compared with the control (Fig. 4).

A

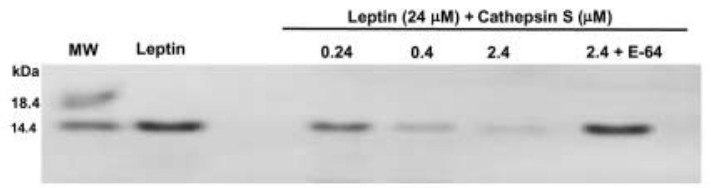

B

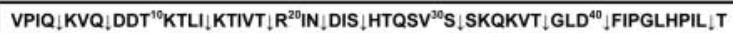

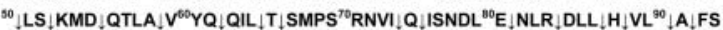

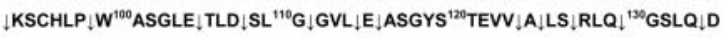

Figure 3 Effect of cathepsin S on leptin and potential cleavage sites. (A) SDS gel electrophoresis (12.5\%) followed by Coomassie blue staining. Recombinant human leptin $(24 \mu \mathrm{M})$ was incubated with $0.24,0.4$, and $2.4 \mu \mathrm{M}$ cathepsin $\mathrm{S}$ for $15 \mathrm{~min}$ in sodium phosphate buffer, $\mathrm{pH}$ 6.0. At the same conditions, $2.4 \mu \mathrm{M}$ cathepsin $\mathrm{S}$ was incubated in the presence of $5 \mu \mathrm{M} \mathrm{E}-64$. The experimental details are described in Materials and Methods section. (B) Proposed cleavage sites (arrows) for cathepsin $\mathrm{S}$ in leptin based on the substrate specificity of the enzyme.
A
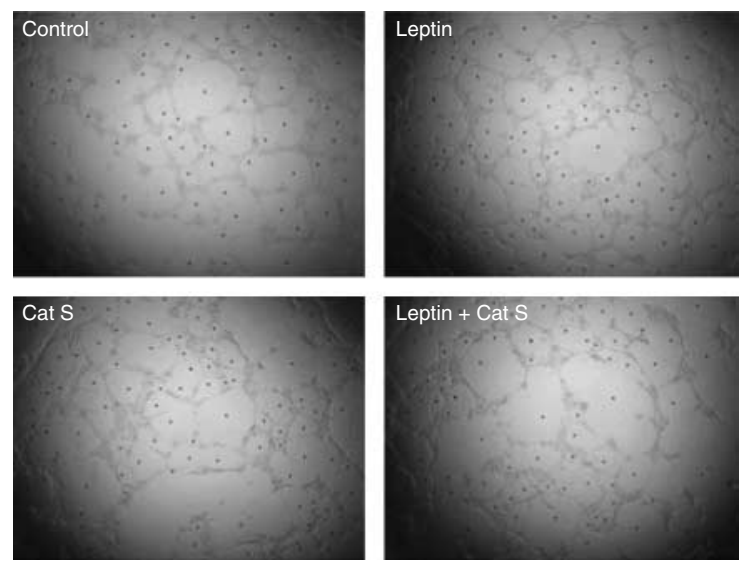

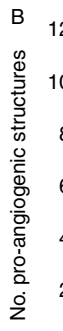

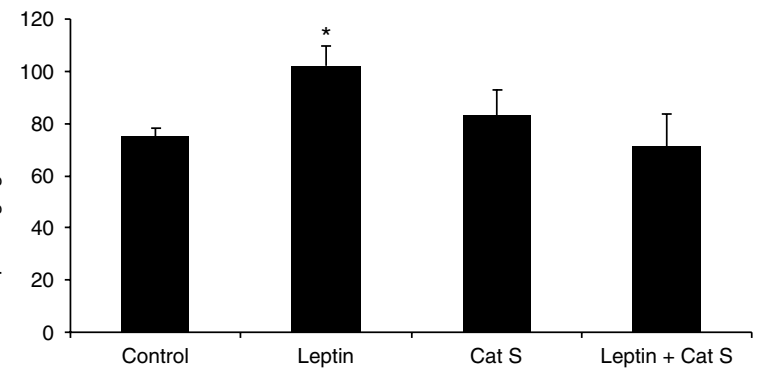

Figure 4 Influence of leptin fragments generated by cathepsin S on angiogenesis. HUVECs (control) were plated on Matrigel in the presence of recombinant human leptin, recombinant human cathepsin S (cat S), and the leptin fragments generated by cathepsin $S$ cleavage. The number of pro-angiogenic structures was counted after $18 \mathrm{~h}$. (A) A representative picture of the different treatments is shown with the respective counts. (B) The results are expressed as the number of pro-angiogenic structures. Data were analyzed using one-way ANOVA followed by Newman-Keuls posttest. $P<0.05$.

Error bars, S.D. of triplicate samples. ${ }^{*}$, denotes statistical significance.

The influence of leptin fragments generated by cathepsin S catalytic activity on food intake was also investigated by performing in vivo assays in Wistar rats (Fig. 5). In these experiments, the leptin fragments were injected into the lateral ventricle (i.c.v.) following the methodology previously described (Telles et al. 2003). The i.c.v. injections of $10 \mu \mathrm{g}$ leptin (group 1), $10 \mu \mathrm{g}$ leptin incubated with $0.24 \mu \mathrm{M}$ cathepsin $\mathrm{S}$ (group 2), and $10 \mu \mathrm{g}$ leptin incubated with $0.24 \mu \mathrm{M}$ heat-inactivated cathepsin S (group 3) showed that on the second and third day, the control group (group 1) exhibited a significant decrease in food intake compared with the first day. However, this effect was not observed when leptin was exposed to the hydrolytic action of cathepsin $\mathrm{S}$ (group 2). Notably, active cathepsin $S$ is required to inactivate leptin once when heat-inactivated cathepsin $\mathrm{S}$ was incubated with leptin (group 3), the food intake was comparable with that of the leptin control group (Fig. 5). The animal weights were measured daily after i.c.v. and no significant variation was observed. 


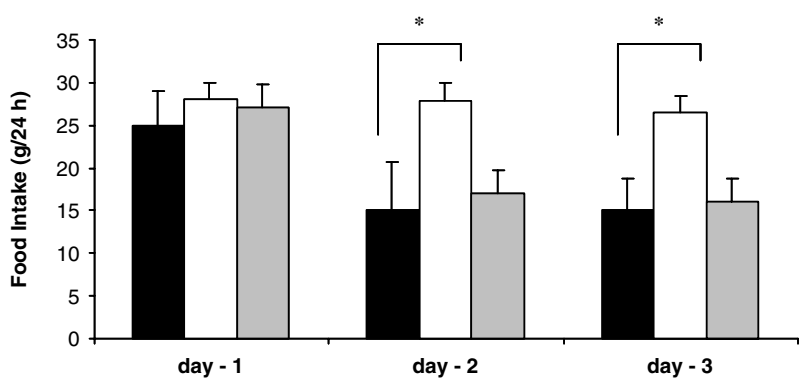

Figure 5 Effect of leptin fragments on rat food intake. Male Wistar rats were submitted to i.c.v. cannula implantation. One week after the surgery, the animals were divided into three groups that received leptin (group 1, black bar), leptin incubated with cathepsin S (group 2, white bar), or leptin incubated with heatinactivated cathepsin S (group 3, gray bar). The injections were repeated for 3 days in $24 \mathrm{~h}$ intervals, and the food intake was measured. The results are shown as means of the food intake. Statistical analysis was performed using two-way ANOVA followed by Bonferroni's posttests. ${ }^{*} P<0.05$.

\section{Discussion}

Since its discovery, leptin physiology and pathology has been extensively studied (reviewed in Lago et al. (2007), Fernandez-Riejos et al. (2010) and Sweeney (2010)). However, leptin-inactivating enzymes have not been described yet, and leptin action is thought to be modulated by biological availability, dictated by the free/bound ratio in plasma and its clearance by the kidneys (Huang et al. 2001, Lammert et al. 2001). In this report, we show that leptin is hydrolyzed by cysteine cathepsins and that cathepsin $\mathrm{S}$ is the most efficient cathepsin in this process. Furthermore, the products of leptin degradation that are generated by cathepsin S catalytic activity are biologically inactive, which places this enzyme at the end point of leptin action.

Cysteine cathepsins were classically known as enzymes involved in protein turnover; however, emerging roles of cathepsins are widely recognized in specific and controlled processes (Turk et al. 2001, Honey \& Rudensky 2003, Turk \& Guncar 2003, Mohamed \& Sloane 2006). Taleb et al. (2006a,b) observed that cathepsin S improved human preadipocyte differentiation and attributed this effect to fibronectin degradation. Although leptin exists in both free and bound fractions, the bound form of leptin would be protected from degradation. Our hypothesis is supported by the impaired adipocyte differentiation and reduced weight gain observed in a diet-induced obese model in cathepsins $\mathrm{L}$ and $\mathrm{K}$ knockout mice and both display a lean phenotype (Funicello et al. 2007, Yang et al. 2007, 2008).

Among the tested enzymes, cathepsin S demonstrated the most significant catalytic activity toward leptin at different $\mathrm{pH}$ values, resulting in very small fragments (Figs 2 and 3). In order to verify whether the generated peptide fragments can still retain biological activity, we performed experiments in vitro and in vivo to analyze the effect of the leptin products generated by cathepsin S (Figs 4 and 5). Our results demonstrated a high efficiency of this enzyme in inactivating the functional activity of leptin.

Enzymatic activities of cathepsins have not been characterized in obesity. However, the cathepsin $\mathrm{S}$ gene expression is described to be more influenced by changes in energy balance than cathepsins L and K (Naour et al. 2010). In addition, cathepsin $\mathrm{S}$ is highly expressed in macrophages (Shi et al. 1992) and increased by pro-inflammatory mediators (Cancello et al. 2005). Because obesity is associated with the infiltration of WAT by macrophages and an increased production of pro-inflammatory adipocytokines (Jobs et al. 2010, Suganami \& Ogawa 2010), it is also reasonable to consider that the low levels of cathepsin S expression observed in epididymal WATs could be improved by cathepsin S from macrophages. Leptin levels are also associated with infection and inflammation (reviewed in Fernandez-Riejos et al. (2010)) and were found to stimulate immune cells, such as macrophages and pro-inflammatory cytokines (Santos-Alvarez et al. 1999, Gruen et al. 2007).

Studies on synthetic peptides demonstrated that the entire leptin molecule is not required for biological activity (Samson et al. 1996, Grasso et al. 1997, de Oliveira et al. 2008, Barrett et al. 2009, 2011, Martins et al. 2009) and leptin fragments have been detected in human serum (Stamatiadis et al. 2004). However, leptin proteolytic processing and identification of its derived active sequences in circulation have not been extensively studied. It has been described that both lysosomal and proteasomal pathways contribute to the degradation of leptin (Rau et al. 1999, Uotani et al. 1999, Lee \& Fried 2006); however, the enzymes involved in the processing have not been identified. This is the first report that leptin action can specifically be halted via hydrolysis by cysteine cathepsins, remarkable by cathepsin S. The results presented here may contribute to the understanding of leptin action and renew the interest in cathepsins as therapeutic targets in obesity treatment. Nevertheless, additional studies are necessary to completely elucidate the biological role of cathepsins in leptin modulation.

\section{Declaration of interest}

The authors declare that there is no conflict of interest that could be perceived as prejudicing the impartiality of the research reported.

\section{Funding}

This work was funded by grants from Fundação de Amparo a Pesquisa do Estado de São Paulo (FAPESP, Proc. 2008/56340-6, Proc. 2008/10700-1, and Proc. 2011/50495-0). Marcela de Oliveira received a scholarship from Conselho Nacional de Pesquisa (CNPq). 


\section{Acknowledgements}

The authors thank Dr Marcio F M Alves for assistance in the expression of the cathepsins and Raquel L Neves for technical assistance.

\section{References}

Anagnostoulis S, Karayiannakis AJ, Lambropoulou M, Efthimiadou A, Polychronidis A \& Simopoulos C 2008 Human leptin induces angiogenesis in vivo. Cytokine 42 353-357. (doi:10.1016/j.cyto.2008.03.009)

Arnlov J 2012 Cathepsin S as a biomarker: where are we now and what are the future challenges? Biomarkers in Medicine 6 9-11. (doi:10.2217/ bmm.11.102)

Attele AS, Shi ZQ \& Yuan CS 2002 Leptin, gut, and food intake. Biochemical Pharmacology 63 1579-1583. (doi:10.1016/S0006-2952(02) 00883-3)

Barrett AJ, Kembhavi AA, Brown MA, Kirschke H, Knight CG, Tamai M \& Hanada K 1982 L-trans-Epoxysuccinyl-leucylamido(4-guanidino)butane (E-64) and its analogues as inhibitors of cysteine proteinases including cathepsins B, H and L. Biochemical Journal 201 189-198.

Barrett GL, Trieu J \& Naim T 2009 The identification of leptin-derived peptides that are taken up by the brain. Regulatory Peptides 155 55-61. (doi:10.1016/j.regpep.2009.02.008)

Barrett GL, Naim T \& Trieu J 2011 Leptin-derived peptides that stimulate food intake and increase body weight following peripheral administration. Regulatory Peptides 170 24-30. (doi:10.1016/j.regpep.2011.05.004)

Bertoni L, Ferretti M, Cavani F, Zavatti M, Resca E, Benelli A \& Palumbo C 2009 Leptin increases growth of primary ossification centers in fetal mice. Journal of Anatomy 215 577-583. (doi:10.1111/j.1469-7580. 2009.01134.x)

Cancello R, Henegar C, Viguerie N, Taleb S, Poitou C, Rouault C, Coupaye M, Pelloux V, Hugol D, Bouillot JL et al. 2005 Reduction of macrophage infiltration and chemoattractant gene expression changes in white adipose tissue of morbidly obese subjects after surgery-induced weight loss. Diabetes 54 2277-2286. (doi:10.2337/diabetes.54.8.2277)

Choe Y, Leonetti F, Greenbaum DC, Lecaille F, Bogyo M, Bromme D, Ellman JA \& Craik CS 2006 Substrate profiling of cysteine proteases using a combinatorial peptide library identifies functionally unique specificities. Journal of Biological Chemistry 281 12824-12832. (doi:10.1074/jbc.M513331200)

Christoffolete MA, Ribeiro R, Singru P, Fekete C, da Silva WS, Gordon DF, Huang SA, Crescenzi A, Harney JW, Ridgway EC et al. 2006 Atypical expression of type 2 iodothyronine deiodinase in thyrotrophs explains the thyroxine-mediated pituitary thyrotropin feedback mechanism. Endocrinology 147 1735-1743. (doi:10.1210/en.2005-1300)

Fernandez-Riejos P, Najib S, Santos-Alvarez J, Martin-Romero C, Perez-Perez A, Gonzalez-Yanes C \& Sanchez-Margalet V 2010 Role of leptin in the activation of immune cells. Mediators of Inflammation 2010 568343. (doi:10.1155/2010/568343)

Funicello M, Novelli M, Ragni M, Vottari T, Cocuzza C, Soriano-Lopez J, Chiellini C, Boschi F, Marzola P, Masiello P et al. 2007 Cathepsin K null mice show reduced adiposity during the rapid accumulation of fat stores. PLoS ONE 2 e683. (doi:10.1371/journal.pone.0000683)

Grasso P, Leinung MC, Ingher SP \& Lee DW 1997 In vivo effects of leptin-related synthetic peptides on body weight and food intake in female $o b / o b$ mice: localization of leptin activity to domains between amino acid residues 106-140. Endocrinology 138 1413-1418. (doi:10.1210/en.138.4. 1413)

Gruen ML, Hao M, Piston DW \& Hasty AH 2007 Leptin requires canonical migratory signaling pathways for induction of monocyte and macrophage chemotaxis. American Journal of Physiology. Cell Physiology 293 C1481-C1488. (doi:10.1152/ajpcell.00062.2007)

Haynes WG 2005 Role of leptin in obesity-related hypertension. Experimental Physiology 90 683-688. (doi:10.1113/expphysiol.2005.031237)
Honey K \& Rudensky AY 2003 Lysosomal cysteine proteases regulate antigen presentation. Nature Reviews. Immunology 3 472-482. (doi:10.1038/ nri1110)

Huang L, Wang Z \& Li C 2001 Modulation of circulating leptin levels by its soluble receptor. Journal of Biological Chemistry 276 6343-6349. (doi:10.1074/jbc.M009795200)

Jobs E, Riserus U, Ingelsson E, Helmersson J, Nerpin E, Jobs M, Sundstrom J, Lind L, Larsson A, Basu S et al. 2010 Serum cathepsin S is associated with serum C-reactive protein and interleukin-6 independently of obesity in elderly men. Journal of Clinical Endocrinology and Metabolism 95 4460-4464. (doi:10.1210/jc.2010-0328)

Kirschke H, Wiederanders B, Bromme D \& Rinne A 1989 Cathepsin S from bovine spleen. Purification, distribution, intracellular localization and action on proteins. Biochemical Journal 264 467-473.

Lafarge JC, Naour N, Clement K \& Guerre-Millo M 2010 Cathepsins and cystatin C in atherosclerosis and obesity. Biochimie $\mathbf{9 2}$ 1580-1586. (doi:10.1016/j.biochi.2010.04.011)

Lago F, Dieguez C, Gomez-Reino J \& Gualillo O 2007 Adipokines as emerging mediators of immune response and inflammation. Nature Clinical Practice. Rheumatology 3 716-724. (doi:10.1038/ncprheum0674)

Lammert A, Kiess W, Bottner A, Glasow A \& Kratzsch J 2001 Soluble leptin receptor represents the main leptin binding activity in human blood. Biochemical and Biophysical Research Communications 283 982-988. (doi:10.1006/bbrc.2001.4885)

Lee MJ \& Fried SK 2006 Multilevel regulation of leptin storage, turnover, and secretion by feeding and insulin in rat adipose tissue. Journal of Lipid Research 47 1984-1993. (doi:10.1194/jlr.M600065-JLR200)

Linnevers CJ, McGrath ME, Armstrong R, Mistry FR, Barnes MG, Klaus JL, Palmer JT, Katz BA \& Bromme D 1997 Expression of human cathepsin K in Pichia pastoris and preliminary crystallographic studies of an inhibitor complex. Protein Science 6 919-921. (doi:10.1002/pro.5560060421)

Lutzner N \& Kalbacher H 2008 Quantifying cathepsin S activity in antigen presenting cells using a novel specific substrate. Journal of Biological Chemistry 283 36185-36194. (doi:10.1074/jbc.M806500200)

Martins MN, Telles MM, Zemdegs JC, Andrade IS, Ribeiro EB \& Miranda A 2009 Evaluation of new leptin fragments on food intake and body weight of normal rats. Regulatory Peptides 153 77-82. (doi:10.1016/ j.regpep.2008.11.013)

Mohamed MM \& Sloane BF 2006 Cysteine cathepsins: multifunctional enzymes in cancer. Nature Reviews. Cancer 6 764-775. (doi:10.1038/ nrc1949)

Naour N, Rouault C, Fellahi S, Lavoie ME, Poitou C, Keophiphath M, Eberle D, Shoelson S, Rizkalla S, Bastard JP et al. 2010 Cathepsins in human obesity: changes in energy balance predominantly affect cathepsin $\mathrm{s}$ in adipose tissue and in circulation. Journal of Clinical Endocrinology and Metabolism 95 1861-1868. (doi:10.1210/jc.2009-1894)

de Oliveira VX Jr, Fázio MA, Santos EL, Pesquero JB \& Miranda A 2008 In vitro evaluation of leptin fragments activity on the $o b$ receptor. Journal of Peptide Science 14 617-625. (doi:10.1002/psc.957)

Oliveira M, Torquato RJ, Alves MF, Juliano MA, Bromme D, Barros NM \& Carmona AK 2010 Improvement of cathepsin $S$ detection using a designed FRET peptide based on putative natural substrates. Peptides 31 562-567. (doi:10.1016/j.peptides.2009.12.027)

Paschoalin T, Carmona AK, Rodrigues EG, Oliveira V, Monteiro HP, Juliano MA, Juliano L \& Travassos LR 2007 Characterization of thimet oligopeptidase and neurolysin activities in B16F10-Nex2 tumor cells and their involvement in angiogenesis and tumor growth. Molecular Cancer 6 44. (doi:10.1186/1476-4598-6-44)

Rau H, Reaves BJ, O'Rahilly S \& Whitehead JP 1999 Truncated human leptin (delta133) associated with extreme obesity undergoes proteasomal degradation after defective intracellular transport. Endocrinology 140 1718-1723. (doi:10.1210/en.140.4.1718)

Sahu A 2004 Minireview: a hypothalamic role in energy balance with special emphasis on leptin. Endocrinology 145 2613-2620. (doi:10.1210/en.2004-0032)

Samson WK, Murphy TC, Robison D, Vargas T, Tau E \& Chang JK 1996 A 35 amino acid fragment of leptin inhibits feeding in the rat. Endocrinology 137 5182-5185. (doi:10.1210/en.137.11.5182) 
Santos-Alvarez J, Goberna R \& Sanchez-Margalet V 1999 Human leptin stimulates proliferation and activation of human circulating monocytes. Cellular Immunology 194 6-11. (doi:10.1006/cimm.1999.1490)

Shi GP, Munger JS, Meara JP, Rich DH \& Chapman HA 1992 Molecular cloning and expression of human alveolar macrophage cathepsin S, an elastinolytic cysteine protease. Journal of Biological Chemistry 267 7258-7262.

Stamatiadis DN, Chan JL, Cogswell R, Stefanopoulou HC, Bullen J, Katsilambros N, Stathakis CP \& Mantzoros CS 2004 Elevated leptin fragments in renal failure correlate with BMI and haematopoiesis and are normalized by haemodialysis. Clinical Endocrinology 60 434-441. (doi:10.1111/j.1365-2265.2004.01999.x)

Suganami T \& Ogawa Y 2010 Adipose tissue macrophages: their role in adipose tissue remodeling. Journal of Lenkocyte Biology 88 33-39. (doi:10.1189/jlb.0210072)

Sukhova GK, Zhang Y, Pan JH, Wada Y, Yamamoto T, Naito M, Kodama T, Tsimikas S, Witztum JL, Lu ML et al. 2003 Deficiency of cathepsin S reduces atherosclerosis in LDL receptor-deficient mice. Journal of Clinical Investigation 111 897-906. (doi:10.1172/JCI14915)

Sweeney G 2010 Cardiovascular effects of leptin. Nature Reviews. Cardiology 7 22-29. (doi:10.1038/nrcardio.2009.224)

Taleb S, Lacasa D, Bastard JP, Poitou C, Cancello R, Pelloux V, Viguerie N, Benis A, Zucker JD, Bouillot JL et al. 2005 Cathepsin S, a novel biomarker of adiposity: relevance to atherogenesis. FASEB Journal 19 1540-1542. (doi:10.1096/fj.05-3673fje)

Taleb S, Cancello R, Clement K \& Lacasa D 2006a Cathepsin S promotes human preadipocyte differentiation: possible involvement of fibronectin degradation. Endocrinology 147 4950-4959. (doi:10.1210/en.2006-0386)

Taleb S, Cancello R, Poitou C, Rouault C, Sellam P, Levy P, Bouillot JL, Coussieu C, Basdevant A, Guerre-Millo M et al. 2006b Weight loss reduces adipose tissue cathepsin $\mathrm{S}$ and its circulating levels in morbidly obese women. Journal of Clinical Endocrinology and Metabolism 91 1042-1047. (doi:10.1210/jc.2005-1601)

Taleb S, Herbin O, Ait-Oufella H, Verreth W, Gourdy P, Barateau V, Merval R, Esposito B, Clement K, Holvoet P et al. 2007 Defective leptin/leptin receptor signaling improves regulatory $\mathrm{T}$ cell immune response and protects mice from atherosclerosis. Arteriosclerosis, Thrombosis, and Vascular Biology 27 2691-2698. (doi:10.1161/ATVBAHA.107.149567)

Tartaglia LA 1997 The leptin receptor. Journal of Biological Chemistry 272 6093-6096.

Telles MM, Guimaraes RB \& Ribeiro EB 2003 Effect of leptin on the acute feeding-induced hypothalamic serotonergic stimulation in normal rats. Regulatory Peptides 115 11-18. (doi:10.1016/S0167-0115(03)00129-0)
Thomas AD, Murray JD \& Oberbauer AM 2004 Leptin modulates fertility under the influence of elevated growth hormone as modeled in $o M t 1 a-o G H$ transgenic mice. Journal of Endocrinology 182 421-432. (doi:10.1677/joe. $0.1820421)$

Turk D \& Guncar G 2003 Lysosomal cysteine proteases (cathepsins): promising drug targets. Acta Crystallographica. Section D. Biological Crystallography 59 203-213. (doi:10.1107/S0907444902021479)

Turk B, Turk D \& Turk V 2000 Lysosomal cysteine proteases: more than scavengers. Biochimica et Biophysica Acta 1477 98-111. (doi:10.1016/S01674838(99)00263-0)

Turk V, Turk B \& Turk D 2001 Lysosomal cysteine proteases: facts and opportunities. EMBO Journal 20 4629-4633. (doi:10.1093/emboj/20.17. 4629)

Turk V, Stoka V, Vasiljeva O, Renko M, Sun T, Turk B \& Turk D 2012 Cysteine cathepsins: from structure, function and regulation to new frontiers. Biochemica et Biophysica Acta 1824 68-88.

Uotani S, Bjørbaek C, Tornøe J \& Flier JS 1999 Functional properties of leptin receptor isoforms: internalization and degradation of leptin and ligandinduced receptor downregulation. Diabetes 48 279-286. (doi:10.2337) diabetes.48.2.279)

Vasiljeva O, Reinheckel T, Peters C, Turk D, Turk V \& Turk B 2007 Emerging roles of cysteine cathepsins in disease and their potential as drug targets. Current Pharmacentical Design 13 387-403. (doi:10.2174/ 138161207780162962)

Yang M, Zhang Y, Pan J, Sun J, Liu J, Libby P, Sukhova GK, Doria A, Katunuma N, Peroni OD et al. 2007 Cathepsin L activity controls adipogenesis and glucose tolerance. Nature Cell Biology 9 970-977.

Yang M, Sun J, Zhang T, Liu J, Zhang J, Shi MA, Darakhshan F, Guerre-Millo M, Clement K, Gelb BD et al. 2008 Deficiency and inhibition of cathepsin K reduce body weight gain and increase glucose metabolism in mice. Arteriosclerosis, Thrombosis, and Vascular Biology 28 2202-2208. (doi:10.1161/ ATVBAHA.108.172320)

Zhang Y, Proenca R, Maffei M, Barone M, Leopold L \& Friedman JM 1994 Positional cloning of the mouse obese gene and its human homologue. Nature 372 425-432. (doi:10.1038/372425a0)

Received in final form 24 May 2012

Accepted 31 May 2012

Made available online as an Accepted Preprint

31 May 2012 